\title{
Influence of Digital Economy on Personnel Training for Hotel and Tourism Business
}

\author{
Chikurova T.Y.
}

\author{
Ural state University of Economics, Yekaterinburg, Russia \\ Corresponding author.Email: Chikurova100@mail.ru
}

\begin{abstract}
Based on a study of foreign and domestic hotel enterprises and travel companies, it can be stated that the hotel and tourism industries are rapidly developing activities and have significant potential in international tourism. This determines the fact that the ongoing development of the digital economy requires considering the problems of training professional specialists for the hotel and tourism business and improving competitiveness at the international level. Despite the various geopolitical problems in the world, these types of activities will find a way out of existing predicaments and meet the expenses using modern digital technologies. Created information databases on regular customers will help to restore the suspended communication and provide them with an increased level of service based on modern technologies of Industry 4.0.
\end{abstract}

Keywords: hotel business, tourism business, industry 4.0, professional personnel, digital economy,

information technology

\section{INTRODUCTION}

Considering geopolitical, geo-environmental and other geo-problems, hospitality and tourism enterprises in the digital economy are seeking to find new approaches to serve their guests. This makes it possible to improve their competitiveness in the domestic and foreign markets.

At the same time, the competitive development of the domestic, hotel and tourism business becomes difficult without specialists with a high level of professionalism. The requirements of the tourism and hospitality business in the new conditions of Industry 4.0 are largely based on the need for high-quality staffing for all types of hotel and tourist enterprises. The problems lie in the multidisciplinary nature of their activities, which, on the one hand, needs personnel of various specialties and qualifications, and on the other hand, new technologies for serving guests. Innovative technologies in the digital economy will solve many problems, but well trained employees are needed for the new economic conditions. These tasks are closely interrelated, since the digital economy affects the training of personnel and on its own needs a trained workforce. Therefore, the requirements for educational institutions are strict. Training in accordance with educational and professional standards still needs to be tested, and the digital economy is already counting on specialists with relevant competencies.

\section{METHODOLOGIES}

The program "Digital economy of the Russian Federation" approved by the Government of the Russian Federation gives the go-ahead for the development of new technologies. This program focuses on the «Strategy for the Development of the Information Society of the Russian Federation for 2017-2030» and proceeds from the fact that the digital economy is an economic activity in which the data presented in digital form are a key factor in production [9]. Processing large amounts of information and using the results of the digital data analysis compared with traditional forms of management allow increasing efficiency of various types of production, technologies, equipment, sale of goods and services.

Content analysis of legislative and regulatory documents allows us to provide the research methodologies with basic terms and concepts. Studying the works of famous domestic and foreign scientists in the field of training personnel for tourism and hotel activities in the context of the development of the digital economy makes it possible to use the accumulated experience and transform existing educational technologies subject to industry 4.0 requirements for increasing labor productivity in the above-identified sectors of the national economy.

The digital economy represents a change in the principles of state and business activities and transformation of the mentality of employees. Therefore, the main task of educational institutions is to review educational programs taking into account new challenges in the economy, industry and society.

\section{THE RESULTS OF THE STUDY}

In the course of the research, the author suggests using modified programs in educational activities that should be based on the principles of formation and development of 
the digital economy and Industry 4.0, which requires the study and generalization of experience in the practical implementation of modern high-tech technologies in an unstable geopolitical situation.

The state program has identified 5 basic directions for the effective management of the country's digital economy:

- normative regulation;

- personnel and training;

- formation of research competencies and technical reserves;

- information infrastructure;

- information security [6].

All these areas are important and interconnected. However, the solution of these issues is impossible without human abilities and potential.

The task of the "human resources for the digital economy" direction is to achieve the following performance indicators by 2024 :

- 120,000 people per year - training of graduates with higher education in the field related to information and telecommunication technologies;

- 800,000 people per year - the number of graduates with higher and secondary education possessing competence in the field of information technology at the global average level;

- $40 \%$ - the proportion of the population with digital skills [4].

When developing professional competencies, a future employee of the hospitality and tourism industry needs to study complex international terminology and legislation of various countries: conventions, declarations, memoranda, codes. This knowledge can only be obtained in the process of training in a secondary vocational or higher educational institutions that prepare specialists in these areas. The system of continuing education and the dual system of training qualified employees are now relevant. On-the-job training can be considered a form of dual education. An employee and a student in one person acquires comprehensive training, expands his theoretical horizons and strengthens his professional competence.

The early research of Chikurova T. Y. and her colleague Kurilova E. V. shows: "The dual system ensures the gradual entry of graduates into labor activity, excluding the stress state caused by the lack of information and necessary practical skills. The dual system allows the employee to perform specific labor actions and develops the ability to work in a team and to be competent and responsible [5].

Through the implementation of dual programs it is possible to expand the range of professional education offered to students: shortening the training period and reducing the cost of educational services, improving the quality of training specialists, the possibility of combining the resources of education, science and business to train highly qualified specialists.

Dual educational programs represent a trend of professional training transformation that expands the opportunities of higher and secondary educational institutions for successful functioning and development in the digital economy.
The forms of internship and advanced training for tourism and hospitality employees are diverse. This includes obtaining a second master's degree in specialized industry universities, and advanced training courses at highly rated state and non-state higher education institutions, as well as the use of various commercial centers and business schools, including distance education systems, which are conveniently based on the digital economy technologies.

Stepwise education is undoubtedly a positive trend: college, bachelor's degree, and master's programs. In this case, "natural selection" occurs, since tourism and hotel activities require special human abilities. Not everyone can easily smile in the most difficult situations.

Practical training provides for mastering the profession from the lowest levels of the hierarchical ladder in the organization. If a student has passed the tests at all stages of practical training, he can become a highly qualified specialist.

Only continuous professional development is the key to the competitiveness of a specialist in the modern information economy. One of the forms of professional development is the regular participation of employees of travel agencies and hotels in scientific and practical conferences, seminars, forums, as well as internships at the best enterprises in the tourism industry and hospitality both in their own country and abroad. So, for example, the students studying at the Department of Tourism Business and Hospitality of the Ural State University of Economics successfully undergo training in France, Spain, Turkey, and Greece. Foreign employers highly appreciate training level of our students and continue long-term cooperation on students' internship programs.

Distance education will be especially popular in the digital economy. Information and communication technologies allow classes to be given outside the classroom. Various programs for training specialists through the Internet save time and money, both for universities and students. Digital education can address learning issues at a distance.

It should be noted, says T. P. Levchenko, that in the context of global tourism development, good command of foreign languages, as well as knowledge of information technologies and the basics of international law are the most important factors in training personnel for the branches under study. At the same time, the development of domestic tourism will require good knowledge in the field of tourism industry, planning of tourist flows, identification and development of tourist resources in certain regions. Therefore, at present, when preparing Bachelor's and Master's students, consideration must be given to the intensity of the digital economy development within the framework of Industry 4.0 in our country [3]. Such spheres of activity as tourism and hotel management are extremely diverse and complex. They include state structures and educational institutions, enterprises and firms, public organizations and businesses. The directions we offer in the field of training for the tourism industry and hospitality are as follows:

- monitoring of the labor market demands for tourism specialists and hotel personnel; 
- development of distance education based on a digital approach in training specialists for the tourism industry; - implementation of educational and professional standards of the main specialities in accordance with the Atlas of new professions.

The results of the implementation of these measures should form the basis for developing new federal state educational standards for higher and secondary vocational education in the areas of training related to the tourism and hospitality industry to meet the requirements of the digital economy.

\section{RESULTS AND DISCUSSION}

Professor A. Fedulin, Rector of the Russian State University of Tourism and Service, Doctor of Historical Sciences notes: "It is clear that when speaking about employees, we mean, first of all, professionally trained personnel with relevant qualifications. Life constantly confirms the correctness of the well-known thesis "Cadres decide everything." For example, a study conducted in 2008 by Cornell University (UK) among 243 top and middle managers of hospitality enterprises in different countries of the world, helped to identify five main factors of concern for industry representatives:

$\begin{array}{ll}\text { - } & \text { personnel; } \\ \text { - } & \text { general economic situation; } \\ \text { - } & \text { level increase; } \\ \text { - } & \text { compervice; }\end{array}$

Importantly, it is personnel problems that occupy the first place among the listed factors" [10].

Really, it is employees who are prepared for complex activities in tourism and hospitality that can quickly solve all arising problems. A modern guest is demanding of service. $\mathrm{He}$ is ready to pay for comfortable accommodation and high-quality tourist services.

One can give an example of how Russian students of the Ural State Economic University during their internship in Greece made important decisions in emergency situations (forest fires) saving the lives of hotel guests. Timely measures taken to evacuate the confused people showed both the students' high level of competence obtained in the course of training, and the character of the future tourism manager, which was manifested in extreme conditions.

O.A. Stepanov states in his article that in general the development of the digital economy can be defined as a way of carrying out social and economic activities based on the use of electronic data [8]. At the same time, the author writes about risk and security management during specialist's training and activities based on digital technologies. Serving hotel guests through digital technologies requires confidentiality of information. Strict compliance with professional ethics and protection of information about personal data of guests raise the requirements for hotel employees.

One can hardly disagree with the scientist's opinion, which reflects the legal aspect, since the protection of the rights of hotel guests and tourists around the world is important in emergencies related to their life and health. Those countries of the world that have a sufficiently large margin of safety in terms of economic and information security are able to protect their guests and tourists.

A.E. Belolipetskaya states that digital technology saves such an irreplaceable resource as time. Reducing time spent on performing certain operations is the most important economic indicator [1]. All organizations in the world strive to increase labor productivity by reducing the time to provide services and perform work. It is digital technologies that will allow Russian enterprises to increase labor productivity and achieve economic efficiency of business. This will directly affect tourism and hospitality organizations and increase their sustainability in industry 4.0.

Doctor of Sciences O.V. Pirogova notes in her work that the level of students' practical training in Russian universities is insufficient. The example of foreign educational institutions of both higher and secondary education demonstrates the experience of creating training hotels. It is very costly for Russian universities. The scientist also suggests preparing specialists with the use of advanced technologies for professional training in the field of tourism. This method, based on the foresight of future trends in the industry, will allow taking timely measures related to a high level of serving guests and providing them with a comfortable stay [7].

The domestic tourism industry is developing domestic and inbound tourism that is more profitable for the economy of the Russian Federation. In the near future international inbound tourism is likely to prevail over outbound tourism or become equal to it in the context of the development of the digital economy in the country. This will change specific professional requirements for future employees and managers of tourism and hospitality enterprises. The world experience in the development of tourism industry and hospitality shows that continuous professional education of employees is a prerequisite for the effective work of enterprises in the digital economy. The forecasts of the UNWTO Academy about the tourism growth at international level in the coming years have become irrelevant due to the coronavirus pandemic. Therefore, this is both an opportunity and a challenge at the same time. The opportunity is to invest and create quality jobs in the tourism sector. The problem is that in order to support the expected growth and achieve the competitiveness and sustainability of the tourism sector, UNWTO member states need a reliable human capital base in the tourism sector that meets current and future market needs and, ultimately, increases the competitiveness and sustainability of tourism destinations [11].

A. Poon, a foreign scientist in the field of tourism, states in his book that, being a complex and multifaceted industry, tourism is facing growing pressure, namely, consumer demand for individual tours to the areas with a clean environment, opportunities provided by new technologies and growing environmental problems. The author analyzes the main challenges to tourism. 


\section{REFERENCES}

A. Poon emphasizes the central role of information technology in the development of mass tourism, as well as the way in which these digital technologies and innovations create new best practices for flexible transformation, segmentation of the tourism and hotel markets for better services [12].

Foreign scientists in their works make the main emphasis on information technologies inherent in the digital economy. Knowledge and skills acquired by students of higher and secondary educational institutions in both fulltime and part-time forms of education should be immensely transformed into mastering the achievements of the digital economy. Booking tours and consulting regular customers in tourism require competence in modern information technologies.

\section{CONCLUSION}

In conclusion, it should be noted that training for the tourism and hotel industry is one of the important socioeconomic problems. In conclusion, it should be noted that training for tourism and hospitality is one of the important socio-economic tasks, since even any common person needs the services of the tourism and hotel industry. Of course, the requirements for the quality of these services are increasing, so the training of highly qualified personnel is on the agenda in the digital economy.

It is the innovative technologies of the digital economy that allow training specialists focused on the future. Competent employees of the tourism business can predict unique tourist routes taking into account the growing needs of tourists. Hotel enterprises with employees having a high level of professional training create comfortable conditions for the reception and accommodation of their guests.

Offering "smart rooms", where many functions are automated, robotic and provide a normal microclimate for guests with various health features, is becoming relevant [13]. All this is possible due to the fact that higher and secondary educational institutions will train specialists upon the request of the digital economy market, since all of the above benefits for guests can be provided only by competent and professionally trained personnel.

Thus, the attention of all stakeholders - the state, business and educational institutions - to solving the problems of building human resources in the tourism industry and hospitality can contribute to a more dynamic development of these areas of tourist services in the digital economy. Improving the quality of tourism and hotel services and the competitiveness of Russian hospitality organizations is feasible in the light of the requirements of the digital economy in the era of industry 4.0 when training highly qualified personnel.
[1] Belolipetskaya A.E, The concept of digital education of training qualified personnel in Russia, Management Issues, No. 5 (48), 2017

[2] Order of the Government of the Russian Federation No. 1632-r dated July 28, 2017 No. 1632-r "On approval of the program for the development of the digital economy in the Russian Federation until 2035"

[3] Levchenko T.P., The development of the market of tourist services in a digital economy [Electronic resource] - Access mode: www.esa-conference.ru

[4] Personnel for the digital economy [Electronic resource] - Access mode: htpp: data- economy.ru

[5] Kurilova E.V., Chikurova T.Yu. Features of training for the tourism industry, Bulletin of Ugra State University. 13, No 4 (2015) S.12-16

[6] Industry 4.0 and the digital economy. [Electronic resource] - Access mode: https://leaderid.ru/event/15535/

[7] Pirogova O.V., The state of training for tourism in the Russian Federation // Contint is licensed under a Creative Commons Attribution 4.0 (CC-BY 4.0) license - Interactive Plus Center for Scientific Cooperation

[8] Stepanov O.A., On important aspects of training for the development of the digital economy, Journal of Russian Rights - No. 11 - 2018 - P.106-111

[9] Decree of the President of the Russian Federation of 05.09.2017 "On the development strategy of the information society of the Russian Federation for 20172030. [Electronic resource] - Access mode: http://www.consultant.ru/document/cons_doc_LAW_2 $16363 /$

[10] Fedulin A. ,Training for tourism: problems and challenges [Electronic resource] - Access mode: http://bujet.ru/article/55618.php

[11] Development of human capital in tourism UNWTO Academy - [Electronic resource] - Access mode: www.unwto.org

[12] Poon A. Tourism, Technology, and Competitive Strategies, CAB International, Oxford, 2013.

[13] Mikhnenko P. A. (2019). Model for labour productivity management in the econ- omy of Russia. Journal of New Economy, vol. 20, no. 5, pp. 42-60. DOI: 10.29141/2658-50812019-20-5-3 